\title{
PROMISING CASTING ALUMINUM ALLOYS WITHOUT REQUIREMENT FOR HEAT TREATMENT
}

\author{
${ }^{1}$ Pavel SHURKIN, ${ }^{1,2}$ Torgom AKOPYAN, ${ }^{1}$ Askar MUSIN \\ ${ }^{1}$ National University of Science and Technology «MISiS», Moscow, Russian Federation, p.shurkin@misis.ru \\ 2Baikov Institute of Metallurgy and Materials Science, Moscow, Russian Federation, imet@imet.ac.ru
}

https://doi.org/10.37904/metal.2019.742

\begin{abstract}
Three kinds of aluminum alloys based on $\mathrm{Al}-\mathrm{Zn}-\mathrm{Mg}$ system and doped with $\mathrm{Ca}, \mathrm{Ni}$ and $\mathrm{Ce}$ were studied. Determination of hot tearing tendency, phase composition and structure formation investigation were conducted. Alloying with the elements of $\mathrm{Ca}, \mathrm{Ni}$, Ce group is effective to increase casting properties that is better than those of a commercial A206 alloy. The structure after slow cooling during sand mold casting contains mainly needle like $\mathrm{Al}_{3} \mathrm{Fe}$. But after permanent mold casting the iron containing phases are only ternary phases $\mathrm{Al}_{10} \mathrm{CaFe}_{2}, \mathrm{Al}_{9} \mathrm{FeNi}$ and $\mathrm{Al}_{10} \mathrm{CeFe}_{2}$. Most of $\mathrm{Zn}$ and $\mathrm{Mg}$ content are in aluminum solid solution as a result of casting that cause of appropriate mechanical properties under as-cast state. Moreover the high content of iron can allow us to include new alloys into the recycled type which means the opportunity to be produced using low grade aluminum or can scrap.
\end{abstract}

Keywords: Casting, Al-Zn-Mg system, nickel, calcium, cerium

\section{INTRODUCTION}

Most of casting aluminum alloys belong to Al-Si $(4 x x)$ system [1,2]. They consist of great many eutectic constituents which make them well-castable by any methods into almost any mold with any configuration. Also these alloys are well known as recyclable that means that they are able to be produced with use a secondary stock $[2,3]$. Thus, they usually contain iron. The non-heat-treatable Al-Si alloys are usually subjected to highpressure die casting (HPDC) and their ultimate tensile strength (UTS) under as-cast state does not exceed $200 \mathrm{MPa}$ or they have low ductility [2,4,5]. Some kinds of Al-Mg (5xx) alloys developed in [6-8] have a very high ductility after HPDC under as-cast state provided by limitation of iron content. In spite of high strain rate these alloys are not secondary type and also they have low yield strength (YS) of less than $200 \mathrm{MPa}$ that is common for $5 x x$ alloys [2].

Al-Zn-Mg (7xxx) alloys have not been considered as non-heat-treatable casting alloys yet. The matrix system provides high mechanical properties after ageing but due to lack of eutectic liquid they usually produced as wrought products [1]. Also a strict limitation of iron is necessary too [1,9]. Nevertheless it looks promising because of some facts linked with their good weldability (in no-cooper containing alloys) and ability to obtain supersaturated solid solution after casting at ease [1]. Some works are devoted to both eutectic forming elements and iron addition [10,11]. In one of these works [11] authors alloyed Al-Zn-Mg matrix with $0.41 \% \mathrm{Fe}$ and $0.55 \% \mathrm{Ni}$ to obtain $\mathrm{Al}{ }_{9} \mathrm{FeNi}$ ternary phase in structure of castings after crystallization under pressure. UTS value was about $500 \mathrm{MPa}$ in T6 state. It could be guessed that Al-Zn-Mg-Ni-Fe alloys are the most studied among Al-Zn-Mg alloys with eutectics. Calcium is equally good to obtain eutectic. It is able to enhance corrosion resistance and make a density lower [12]. Al-Zn-Mg-Ca-Fe alloys were considered in an only study [10]. They showed a positive effect of iron on hardness due to its reaction with aluminum and calcium forming an $\mathrm{Al}_{10} \mathrm{CaFe}_{2}$ phase and $(\mathrm{Al}, \mathrm{Zn})_{4} \mathrm{Ca}$ phase content reduction. No tensile properties were presented. Cerium is also forming the same phases $\mathrm{Al}_{10} \mathrm{CeFe}_{2}$ and $\mathrm{Al}_{4} \mathrm{Ce}$ of eutectic origin [14]. But it has never been presented in Al-Zn-Mg alloys. The only work considers Al-Zn-Mg-Cu alloy doped with no more than $0.4 \mathrm{wt} \% \mathrm{Ce}$ [15]. Despite the positive grain refinement effect the coarse $\mathrm{Al}_{8} \mathrm{Cu}_{4} \mathrm{Ce}$ appears. Due to this fact and according to some recommendations [2] alloying with cooper is not considered in this study. 
This work aims to substantiate a principal opportunity to obtain new promising high strength aluminum alloys based on the $\mathrm{Al}-\mathrm{Zn}-\mathrm{Mg}-\mathrm{Ni}(\mathrm{Ca}, \mathrm{Ce})-\mathrm{Fe}$ system for use under as-cast state by determination of casting properties, microstructure and mechanical properties investigation.

\section{EXPERIMENT}

An initial matrix system Al-5.5 wt $\% \mathrm{Zn}-1.5 \mathrm{wt} \% \mathrm{Mg}$ was alloyed with $0.5 \mathrm{wt} \% \mathrm{Fe}$ and separately doped with 1 $\mathrm{wt} \% \mathrm{Ni}, 1 \mathrm{wt} \% \mathrm{Ca}$ and $1 \mathrm{wt} \% \mathrm{Ce}$. These three kinds of alloys were obtained by smelting pure materials and master alloys: aluminum (purity of $99.8 \%$ ), zinc (purity of $100 \%$ ), magnesium (purity of $100 \%$ ), cerium (purity of $100 \%$ ), master alloys Al-10 wt \% Fe, Al-15 wt \% Ca and Al-20 wt \% Ni. The melting temperature was no more than $850{ }^{\circ} \mathrm{C}$ and casting temperature was $720-730{ }^{\circ} \mathrm{C}$. The melts purification was conducted by $\mathrm{C}_{2} \mathrm{Cl}_{6}$ powder injection covered with aluminum foil. The experimental chemical composition (Table 1) was determined by spectral analysis in ARL3460 emission spectrometer. It could be seen that the experimental concentrations are enough close to the theoretical ones.

Table 1 Chemical composition of experimental alloys

\begin{tabular}{|c|c|c|c|c|c|c|c|}
\hline \multirow{2}{*}{$\begin{array}{c}\text { Alloy } \\
\text { designation }\end{array}$} & \multicolumn{7}{|c|}{ Concentrations (wt\%) } \\
\cline { 2 - 8 } & $\mathbf{Z n}$ & $\mathbf{M g}$ & $\mathbf{N i}$ & $\mathbf{C a}$ & $\mathbf{C e}$ & $\mathbf{F e}$ & $\mathbf{A l}$ \\
\hline $\mathbf{A 1}$ & 5.61 & 1.65 & 0.84 & - & - & 0.44 & Balance \\
\hline A2 & 5.48 & 1.44 & - & 0.91 & - & 0.47 & Balance \\
\hline A3 & 5.60 & 1.38 & - & - & 1.11 & 0.45 & Balance \\
\hline
\end{tabular}

Pensil-type hot tearing test castings with diameters of $16,14,12$, and $10 \mathrm{~mm}$ were obtained. The cooling rate was at least $20^{\circ} \mathrm{C} / \mathrm{s}$. The microstructure analysis was carried out by scanning electron microscopy (SEM) TESCAN VEGA 3 and electron microprobe analysis (Oxford AZtec). Specimens were polished using a diamond suspension with 9,6 , and $3 \mu \mathrm{m}$ fractions. They also were subjected to electrolytic etching at $12 \mathrm{~V}$ in $6 \mathrm{C}_{2} \mathrm{H}_{5} \mathrm{OH}: 1 \mathrm{HClO}_{4}: 1$ glycerin water solution. To investigate equilibrium structure specimens after slow cooling (less than $5^{\circ} \mathrm{C} / \mathrm{s}$ ) in sand mold were obtained. Also some bars permanent mold castings with a massive bob of about $600 \mathrm{~g}$ were obtained (Figure 1). They were mechanically processed for tensile test samples which were subjected to room temperature uniaxial test at Z250 Zwick/Roell machine in an as-cast state.

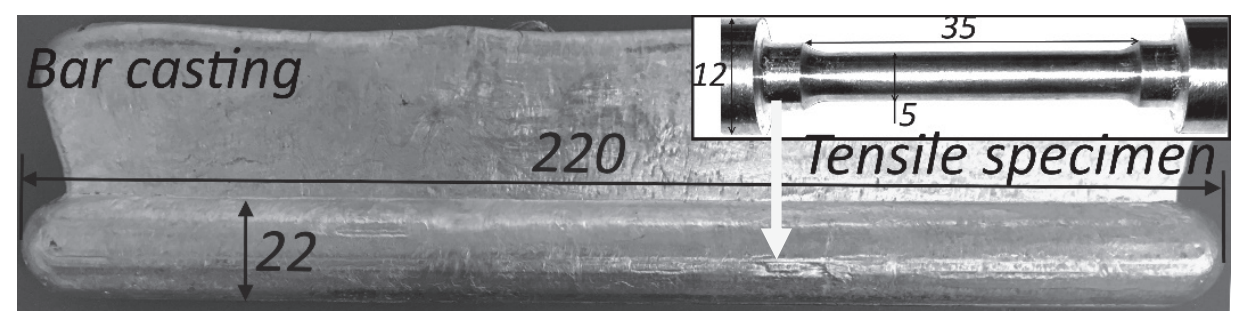

Figure 1 Bar permanent casting

\section{RESULTS AND DISCUSSION}

Hot tearing tendency appears due to low ductility in solid-liquid state. This state occurs during effective solidification range. This means a formation of solid body of casting that is too fragile and undergoes to shrinkage. A well-known temperature of non-equilibrium solidus in Al-Zn-Mg system is about $483^{\circ} \mathrm{C}$, therefore a solidification range is too wide compared to Al-Si alloys. At this temperature T phase $\left(\mathrm{Al}_{2} \mathrm{Mg}_{3} \mathrm{Zn} \mathrm{n}_{3}\right)$ appears. Due to dissolution of some $\mathrm{Zn}$ and $\mathrm{Mg}$ in (Al) there is a lack of eutectic liquid to fill the emerged cracks. In this case the alloying with iron and eutectic forming elements contributes to formation of non-soluble AlgFeNi, 
$(\mathrm{Al}, \mathrm{Zn})_{4} \mathrm{Ca}, \mathrm{Al}_{10} \mathrm{CaFe}_{2}, \mathrm{Al}_{10} \mathrm{CeFe}_{2}$ and $\mathrm{Al}_{4} \mathrm{Ce}$ phases of equilibrium eutectic origin at temperature above $500{ }^{\circ} \mathrm{C}[2,10,14]$. At implemented solidification rates a lower border of the effective solidification range may shift to equilibrium solidus border. Thus, a brittleness temperature range is narrower and crystallizing equilibrium eutectic which crystallizes the last is relatively enough to fill hot cracks. This was confirmed during hot tearing tendency test. Figure 2 indicates on better casting properties of the experimental alloys A1, A2, A3 than those of a reference commercial A206 (Al-5 wt\% Cu).
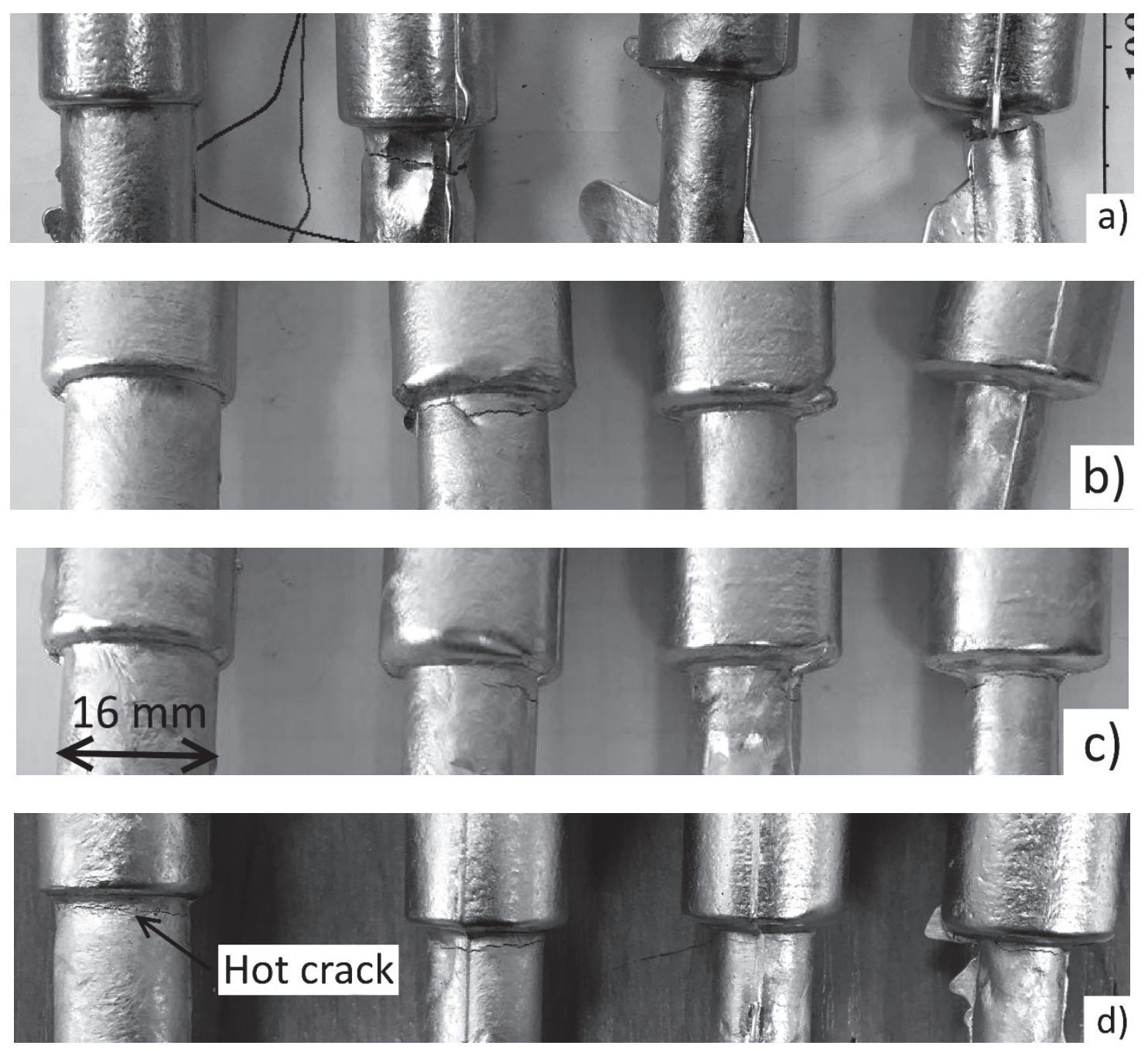

Figure 2 Pencil-type hot tearing test castings:

(a) A1 alloy; (b) A2 alloy; (c) A3 alloy; (d) A206 commercial alloy

The appropriate casting properties provided by specific solidification may not be achieved at lower solidification rate. Figure 3 is dedicated to microstructures after slow cooling. They contain a great many needle like phases which are most likely to be $\mathrm{Al}_{3} \mathrm{Fe}$ phase. Meanwhile, at similar conditions $\mathrm{A} 1$ alloy predominantly consists of needle-like constituents of different color (Figure 3a). Some of them are probably $\mathrm{Al}_{3} \mathrm{Ni}$ phase. Besides needle phase, A2 alloy with calcium contains also a fishbone type phase which is most likely to be $(\mathrm{Al}, \mathrm{Zn})_{4} \mathrm{Ca}$ (Figure 3b). A3 alloy looks a bit finer due to specific $\mathrm{Al}_{3} \mathrm{Fe}$ phase shape. They are predominantly separated as star shaped inclusions of about $20-30 \mu \mathrm{m}$ of secondary crystallization origin. These structures looks unfavorable to obtain high ductile and due to this fact the new promising alloys are to be produced by permanent mold casting. But we assume that the same alloying approach may be effective to develop alloys for sand molds casting too. 

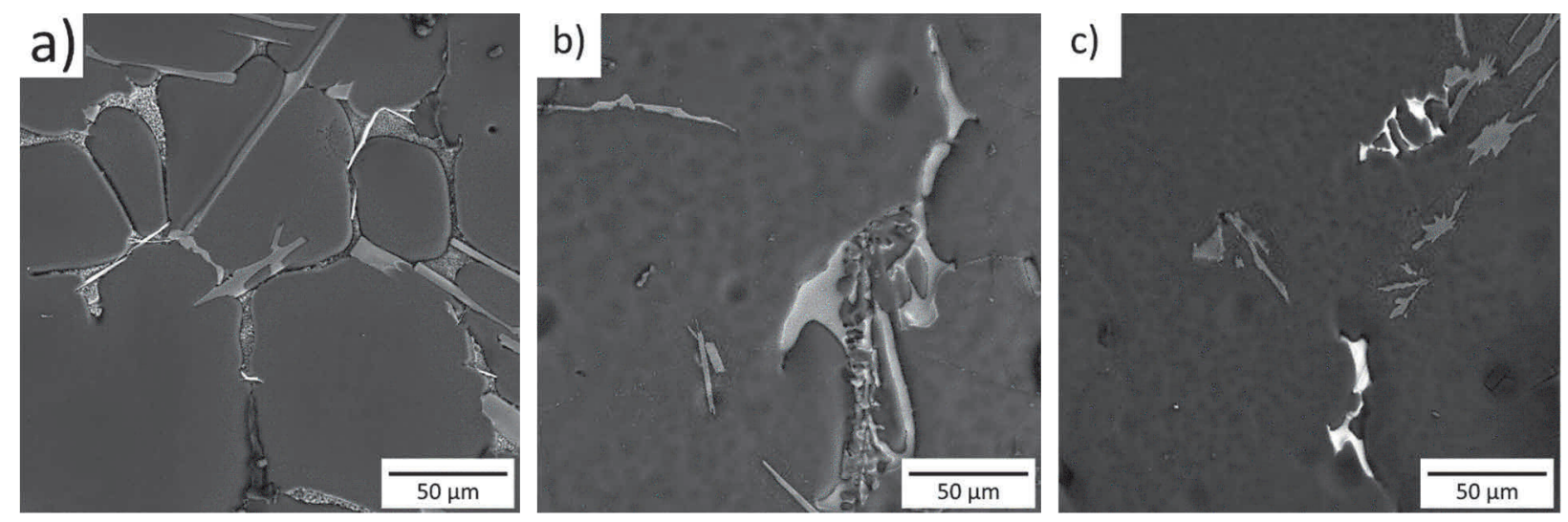

Figure 3 As-cast microstructures of experimental alloys after slow cooling:

(a) A1 alloy; (b) A2 alloy; (c) A3 alloy

Microstructures of the permanent mold castings are much finer. Figure $4 a$ shows a structure of the A1 nickelcontaining alloy. Many studies show that this type of alloy is a great one to be subjected to spheroidizing heat treatment and produced as shape castings and wrought products with high ductility and strength. The presented structure contains enough rounded and small plates shape intermetallics with almost the same both content of nickel and iron that matches to AlgFeNi phase. An aluminum solid solution is in supersaturated state despite the T phase presence. All eutectic consistuents are in the dendritic cells boundaries and they mostly are not in a bonded state, that is able to contribute to ductile failure during tensile test. Figure $\mathbf{4 b}$ is dedicated to structure of the A2 calcium-containing alloy. There are separated eutectic consistuents too there, but due to specific $(\mathrm{Al}, \mathrm{Zn})_{4} \mathrm{Ca}$ formation, it contains fishbone shape inclusions. It is a bit complicated to identify $\mathrm{Al}_{10} \mathrm{CaFe}_{2}$ phase, but the presence of iron in eutectic and lack of needle shaped phases indicates on its occurrence. The A3 cerium-containing alloy structure (Figure 4c) is comparable to those of the A1 alloy. Indication of iron-containing $\mathrm{Al}_{10} \mathrm{CeFe}_{2}$ phase is more apparent and the whole composition of the presented microprobe analysis result points on a small amount of $T$ phase. Aluminum solid solution in the A2 and A3 samples is also supersaturated with almost the same amount of $\mathrm{Zn}$ and $\mathrm{Mg}$ as it was in (Al) of the A1 sample. This contributes to solid solution effect and enchases the strength due to aluminum lattice bending.

Eventually all the presented structures of experimental alloys as permanent mold castings look more favorable than structures of Al-Si alloys presented in Figure $\mathbf{4 d}$ (Al7Si0.3Mg alloy) and Figure 4 e (Al12Si2Cu alloy). These reference alloys are extensively used in automotuve industry. Even if Al7Si0.3Mg could be modified with $\mathrm{Sr}$ and obtain fine structure it would need a heat treatment. And there are often a primary (Si) crystals formation occurs in Al12Si2Cu alloy.
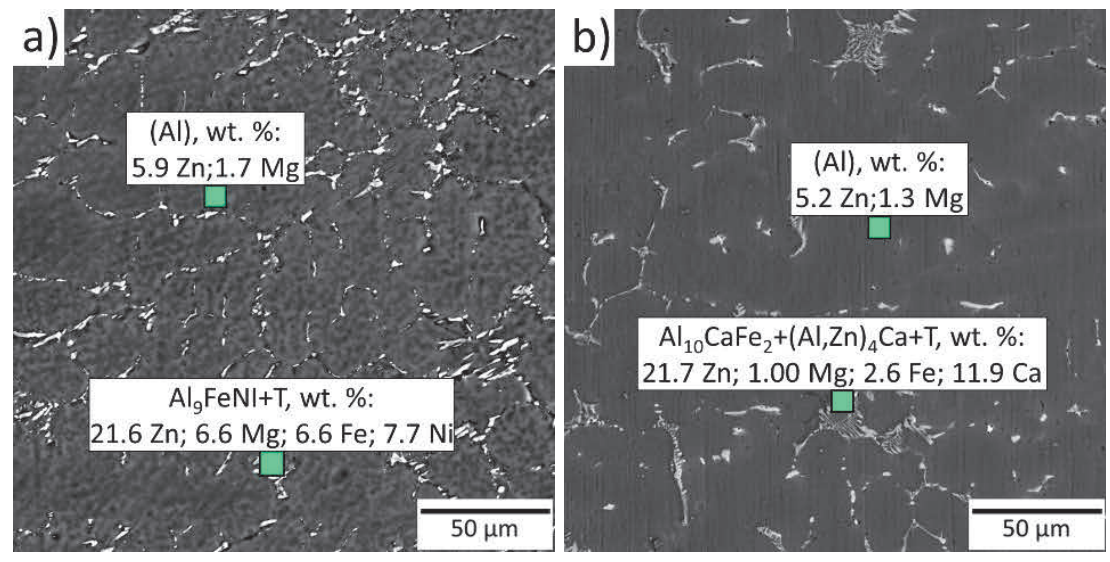

Figure 4/1 As-cast microstructures of experimental alloys after permanent mold casting:
(a) A1 alloy;
(b) A2 alloy;
(c) A3 alloy; (d)
(d) Al7SiO.3Mg alloy; (
(e) Al12Si2Cu alloy; 

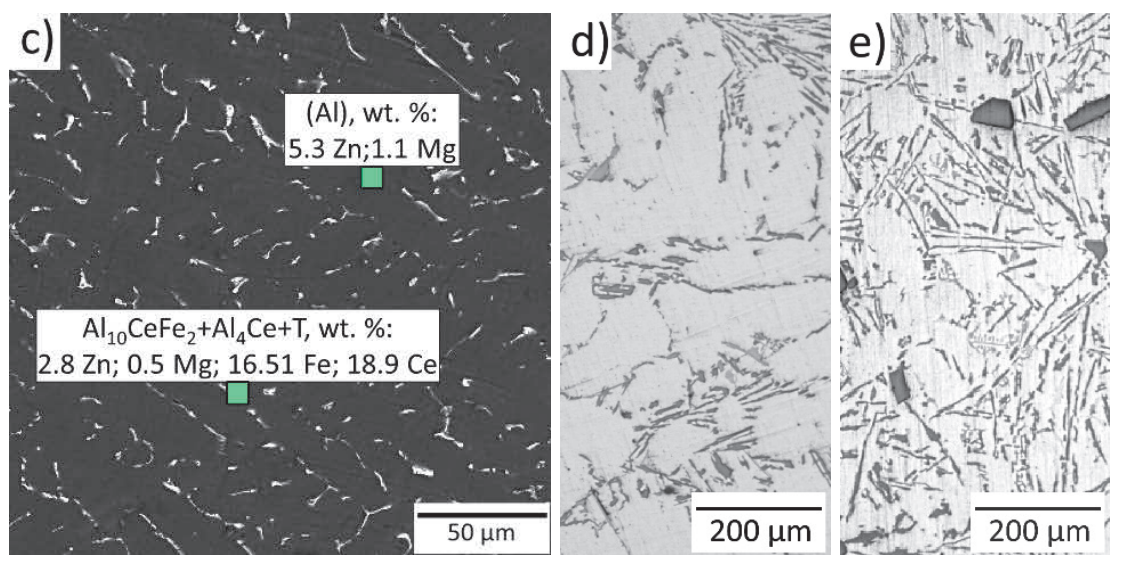

Figure 4/2 As-cast microstructures of experimental alloys after permanent mold casting:

(a) A1 alloy; (b) A2 alloy; (c) A3 alloy; (d) Al7Si0.3Mg alloy; (e) Al12Si2Cu alloy;

Figure 5 shows the tensile properties of experimental alloys under as-cast state. The properties of the A1 and A2 alloys are similar. UTS value of more than $330 \mathrm{MPa}$ and YS value of more than $220 \mathrm{MPa}$ have been achieved. The elongation is more than $5 \%$. The A3 alloy has a great reserve to be strengthened due to low YS value and the highest elongation. The whole results show a great advantage of the new promising alloys over commercial non-heat-treatable casting aluminum alloys.
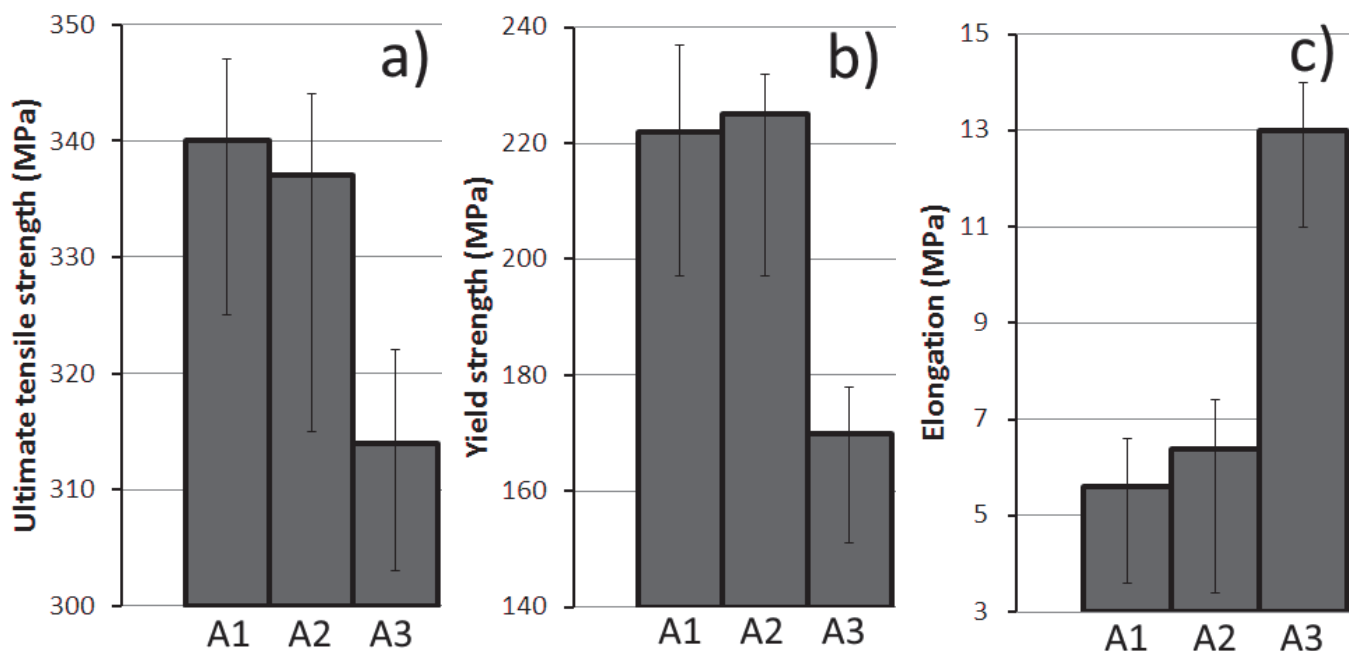

Figure 5 Tensile properties of experimental alloys under as-cast state: (a) UTS; (b) YS; (c) El

\section{CONCLUSION}

New generation promising casting aluminum alloys was studied under as-cast state. The efficiency of eutecticforming elements from $\mathrm{Ni}, \mathrm{Ca}, \mathrm{Ce}$ group and iron in hot tearing resistance enhance was substantiated. All the experimental alloys had better casting properties than those of A206 commercial alloy. The opportunity to obtain fine dispersed structure contained iron-containing ternary phases $\mathrm{Al}_{9} \mathrm{FeNi}, \mathrm{Al}_{10} \mathrm{CaFe}_{2}$ and $\mathrm{Al}_{10} \mathrm{CeFe}_{2}$ after permanent mold casting was confirmed. Both the intermetallics of eutectic origin distribution and supersaturated solid solution provide high mechanical properties which are exceeding those of existing commercial casting non-heat-treatable aluminum alloys. Moreover high content of iron provide the opportunity to obtain them using secondary stock or low-grade pure aluminum. 


\section{ACKNOWLEDGEMENTS}

\section{The work has been performed within a State Assignment of the Ministry of Education and Science of Russia, Project No. 11.2072.2017/4.6}

\section{REFERENCES}

[1] HATCH, J.E. Aluminum: Properties and Physical Metallurgy. Ohio: American Society for Metals, 1984. p. 424.

[2] GLAZOFF, M., KHVAN, A., ZOLOTOREVSKY, V., BELOV, N. and DINSDALE, A. Casting Aluminum Alloys. Their Physical and Mechanical Properties. 2nd Edition: Elsevier, 2018. p. 608

[3] ZÁVODSKÁ, D., TILLOVÁ, E., ŠVECOVÁ, I., KUCHARIKOVÁ, L. and CHALUPOVÁ, M. Secondary Cast AlAlloys with Higher Content of Iron. Materials Today: Proceedings, vol. 5, 2018, pp. 26680-26686.

[4] DONG, X., YANG, H., ZHU, X. and JI, S. High strength and ductility alumin9um alloy processed by high pressure die casting. JALCOM. 2019. vol. 773, pp. 86-96.

[5] YANG, H., JI S. and FAN, Z. Effect of heat treatment and Fe content on the microstructure and mechanical properties of die-cast Al-Si-Cu alloys. Materials \& Design. 2015. vol. 85, pp. 823-832.

[6] JI, S., WATSON, D., FAN, Z. and, WHITE, M. Development of a super ductile diecast Al-Mg-Si alloy. Mat. Sci. \& Eng. A. 2012.vol. 556 pio 824-833.

[7] ZHANG, P., LI, Z., LIU, B., DING, W. and PENG, L. Improved tensile properties of a new aluminum alloy for high pressure die casting. Mat. Sci. \& Eng. A. 2016. vol. 651, pp. 376-390.

[8] HU, Z., WAN, L., WU, S., WU, H. and LIU, X. Microstructure and mechanical properties of high strength diecasting Al-Mg-Si-Mn alloy. Materials \& Design. 2013. vol. 46, pp. 451-456.

[9] BENEDETTI, A.V., CABOT, P.L., GARRIDO, J.A. and MOREIRA, A.H. Influence of iron addition on the microstructure and the electrochemical corrosion of Al-Zn-Mg alloys. J. App. Electrochem. 2001. vol. 31, issue 3, pp. 293-300.

[10] SHURKIN, P.K., DOLBACHEV, A.P., NAUMOVA, E.A. and DOROSHENKO, V.V. Effect of iron on the structure, hardening and physical properties of the alloys of the Al-Zn-Mg-Ca system. Tsvetnye Metally. 2018. no. 5, pp. 6977.

[11] MANN, V.Kh., ALABIN, A.N., KROKHIN, A.Yu., FROLOV, A.V. and BELOV, N.A. New generation of high strength aluminum casting alloys. Light Metal Age. 2015. vol. 73, No. 5, pp. 44-47.

[13] VOLKOVA, O.V., DUB, A.V., RAKOCH, A.G., GLADKOVA, A.A. and SAMOSHINA, M.E. Comparison of pitting corrosion tendency for castings made of Al6Ca, Al1Fe, Al6Ca1Fe experimental alloys and AK12M2 industrial alloy. Izvestiya Vuzov Tsvetnaya Metallurgiya (Proceedings of Higher Schools Nonferrous Metallurgy). 2017. vol. 5, pp. 75-81.

[14] GOTO, S., KIM, B-II., PARK, H.-H., BELOV, N.A., ZOLOTOREVKIJ, V.S., ASO, S. and KOMATSU Y. Application of multiphase eutectics to development of high strength cast aluminum alloys. Journal of Society of Materials Engineering for Resources of Japan. 2002. vol. 15, no. 2, pp. 66-73.

[15] LAI, J.-P., JIANG, R.-P., LIU, H.-S., DUN, X.-L., LI, Y.-F. and LI, X.-Q. Influence of cerium on microstructures and mechanical properties of Al-Zn-Mg-Cu alloys. Journal of Central South University. 2012. vol. 19, issue 4, pp. 869874. 